\title{
Heinrich Glück, Die Beiden "Sassanidischen" Drachenreliefs (Grundlagen zur Seldschukischen Skulptur)
}

\section{John Shapley}

To cite this article: John Shapley (1920) Heinrich Glück, Die Beiden "Sassanidischen"

Drachenreliefs (Grundlagen zur Seldschukischen Skulptur), The Art Bulletin, 3:3, 132-138, DOI: 10.1080/00043079.1920.11409695

To link to this article: http://dx.doi.org/10.1080/00043079.1920.11409695

曲 Published online: 22 Dec 2015.

Submit your article to this journal $[\pi$ 


\section{REVIEWS}

Heinrich Glïck, Die Beiden "Sassanidischen" Drachenreliefs (Grundlagen zur Seldschukischen Skulptur), Constantinople, Publikationen der Kaiserlich Osmanischen Museen, IV, 1917, 64 pp.; 5 pls.; 8vo.

Most people are interested only in the results of a book of this kind, and for them one can say briefly that Glück shows that the two dragon reliefs in the Constantinople museum nos. 790 (1164) \& 791 (1163) are Turkish, as Strzygowski has held, instead of Sassanian as Sarre and Mendel thought., Pl. XI.

For those few interested in the method of a book of this kind Glück's work has exceptional importance in a different way. It is a practical application of a method of art study gradually evolved and formulated by Strzygowski and presented by him in a number of his recent publications.

Strzygowski's method of study was first introduced to English readers in his article entitled Turner's Path from Nature to Art, Burlington Magazine, XII, 335. In that article the points of view from which a work of art should be studied were given in a tabular form of which I give both the English and the original German versions; the latter, of course, is preferable.

\begin{tabular}{|c|c|c|}
\hline \multirow[b]{2}{*}{$\begin{array}{c}\text { Objective representation } \\
\text { (Nature) }\end{array}$} & Meaning & Appearance \\
\hline & Thing & Shape \\
\hline $\begin{array}{l}\text { Subjective effect } \\
\text { (Art) }\end{array}$ & ance & Pictorial sy \\
\hline
\end{tabular}

\begin{tabular}{|c|c|c|}
\hline & Bedeutung & Erscheinung \\
\hline $\begin{array}{c}\text { Objective Darstellung } \\
\text { (Natur) }\end{array}$ & $\begin{array}{l}\text { Gegenstand } \\
\text { (Goethe: Stoff) }\end{array}$ & $\begin{array}{c}\text { Gestalt } \\
\text { (Daseinsform) }\end{array}$ \\
\hline $\begin{array}{l}\text { Subjective Wirkung } \\
\text { (Kunst) }\end{array}$ & $\begin{array}{c}\text { Inhalt } \\
\text { (Goethe: seelischer } \\
\text { Gehalt) }\end{array}$ & $\begin{array}{c}\text { Form } \\
\text { (Wirkungsform) }\end{array}$ \\
\hline
\end{tabular}

In comparison with the formulation at which Strzygowski has arrived today the above is simple. But even this early version of the table is full enough to show that 


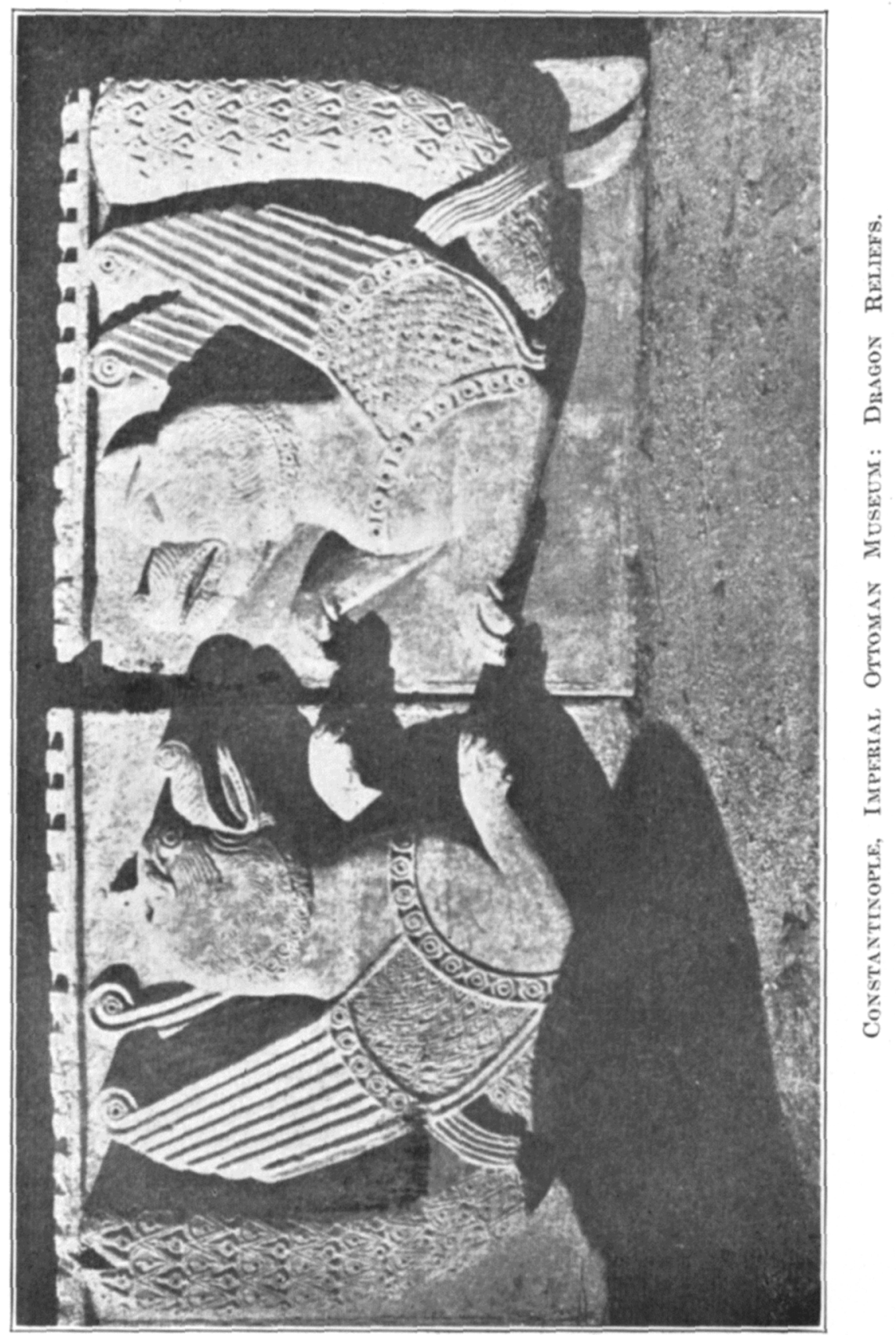


its pedigree can be traced back to the encyclopredic thinking of the early nineteenth century. Strzygowski invokes Goethe.

Although the author of the table above had doubtless been reflecting on some of its fundamental concepts for a long time prexiously, it is not until the publication in $190 \mathrm{~T}$ of his book Die bildende Kunst der Gegenuart that this thinking became fully articulate. The anonymous reviewer of this little book in the Burlington Magazine, XI, 345, saw with surprising clearness the difficulties connected with the isolation and analysis of Gegenstand and Inhalt. Since that time the method of study has figured repeatedly in Strzygowski's numerous writings. There is a convenient bibliography of the subject up to 1917 in the Neue . Nahrbücher für das klassische Altertum, $\mathrm{XL}, 210$.

For a final statement of the method of study it will be necessary to await the forthcoming introductory volume of the Handbuch der Kunstwissenschaft. One may, however, from the frequent references in other connections construct the present form of this method somewhat completely as below, and it is this table, rather than the embryonic one given above, to which I wish to refer. One needs to study it rarefully.

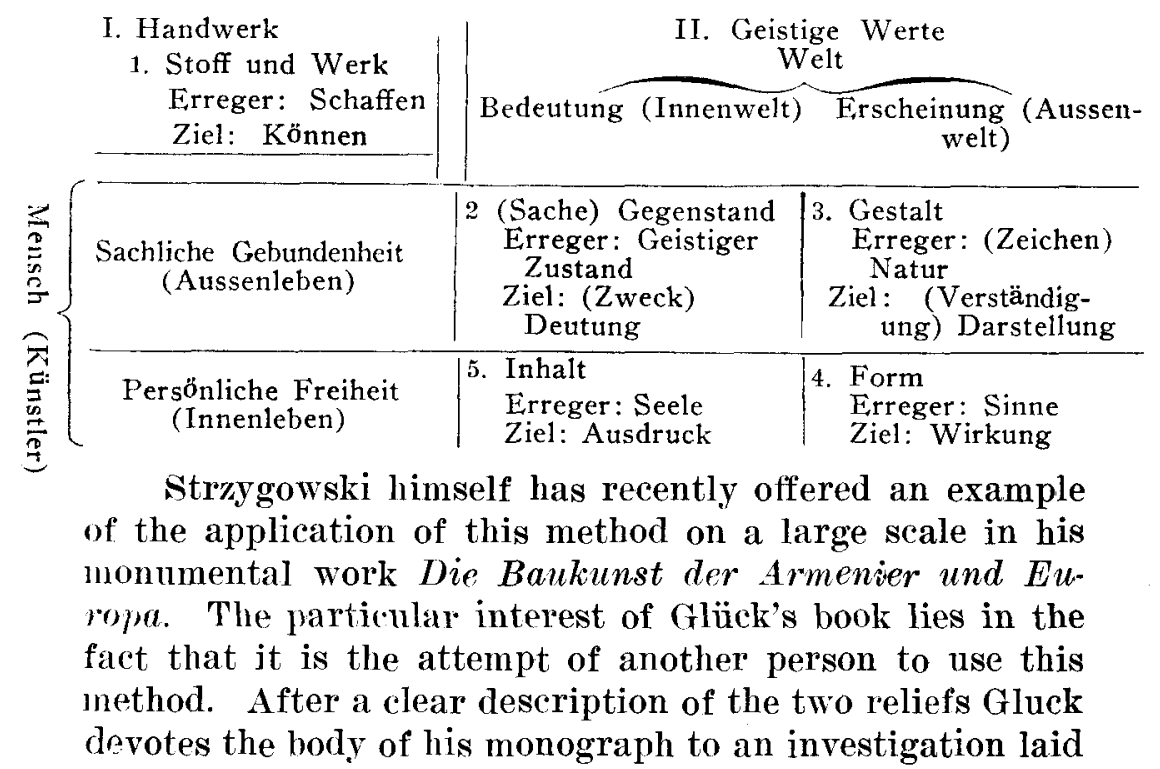


out according to the table just given. He is not, however, able to conform precisely to the table. His variations from it are, I believe, an important because unconscious criticism of it. We encounter one of them at the very outset, since the first section of the investigation, 1 . Architektonische Veruendung, corresponds to nothing in the table. Passing by it for the present we come to 2 . Material and 3. Technik. These correspond to the stoff mnd Werk of the table above: in fact, Strzygowski has often used the expression Material und Technik in this place. Then follows in Glück's investigation, 4. Der dargestellte Gegenstand und seine Bedeutung, 5. Der gestalt. Tiche Typus und scin. Vorliommen, 6. Die formal künstlerische Behandlung. These correspond respectively to the Gegenstand, Gestalt, and Form of the table. Next we should expect something to correspond to Inhalt. As a matter of fact we do not find it. For the investigation comes to an end, and there succeeds only a short concluding chapter in which the character and spirit of Seljuk sculpture are summarized without a word about Inhalt.

What has become of the Inhalt? Strzygowski considers it the goal of his whole series. He reserves it to the last that it may be approached with all the advantages derived from the study of the other aspects of the work of art. Its omission here cannot, therefore, be accidental. Perhaps we can explain this omission from a reëxamination of the table above.

Let me preface this examination with the statement of the purpose of the table. One of the potent influences upon on modern scholarship has been the famous $\tilde{F}_{c o l}$, des Chartes. It s own pupils have not been so numerous, but they have proved sufficient to fructify French learning. And its careful systematic way of studying historical material has found an appreciative echo elsewhere. Particularly at Vienna there has flourished a similar strict tradition. By Wickhoff and others it was turned most effectively toward the study of art history. Strzygowski, however, represents another generation that desires to replace this tradition. In the place of the philological and historical method, he wishes to install an independent method that will establish the study of art as an independent discipline. He has set out to find a method of his own. While 
the Wickhoff tradition has crystallized into such a form as we see in the recent book of Tietze, Die Methode der Kunstgeschichte, Strzygowski's method has crystallized into the form of the table above.

In this table there is first a division between the material and the mental considerations. The material considerations occupy small space, it is true; but, thanks to Semper, no one can forget them nowadays. They occupy the first place in the table without being an integral part of its interlocking construction, something as a front stoop occupies the most conspicuous place without being structurally a part of the house. It is worth noting that they were lacking in the older form given in connection with Turner!

The remainder of the table is an attempt to get at the relation of the artist to his environment, the relation of man to world. The dualism already started continues itself here as a self-reproductive system. World is interpreted as twofold, meaning and appearance (a now somewhat old-fashioned dualism); man is interpreted as determined and free. By this principle of division we have instead of the single meeting point of man and world, the four meeting points of the table, Nos. $2,3,4,5$, of the table. Obviously the whole rests on far-reaching assumptions. The assumption of a fundamental difference between meaning and appearance, doubtful enough in other directions, seems doubly so in connection with art. But this is no place for philosophical reflection. It is more to the point to see how the concrete application offered by Glück works ont. Let us return to that.

Glück's thesis is that the two reliefs are not Sassanian but Turkish.

Finst, in his section on Material, Glück shows that the marble of these reliefs is not that of Persia and that, in fact, marble incrustation was not a Sassanian custom. Rather, the material and the way it was attached to a background suggest Ala-eddin's wall of Konia, whence similar fragments have come. Continuing with the study of Technik, he points out that the peculiar bevelling is not sassamian.

Second, the investigation of the Gegenstand leads to the discovery that the two dragons are differentiated with 
the intention, presumably, of making them male and female. This differentiation does not occur in the preIslamic art of the Near East. It is a thing met with in China and Central Asia. As such it could have been brought from that region only by the people who were in touch with that region, namely, the Turks.

Third, in his study of the Gestalt Glück finds that there are twenty close parallels, which, though of very diverse date and provenience, can all be brought into connection with the migrations from Central Asia.

Fourth, a consideration from the point of view of Form reveals that the reliefs are unlike Sassanian work and are like Turkish work (e. g., at Konia) in the predominance of the front plane, despite the depth of the relief, and in the mass composition in contrast to Sassanian line composition.

It is clear from the above that, although nothing is said of the putative Inhalt, Glück has well substantiated his thesis from these various directions. Furthermore, it remains for us to speak of the first section of the investigation, Architektonische Verwendung, in which it is shown that the way the reliefs were framed (with inverted dentils) to bring them into the level of the wall surface, is characteristic of Turkish not Sassanian architecture.

The absence of any discussion of Inhalt arouses our 'uriosity as to what Glück missed. This curiosity is not easily satisfied. We turn for aid immediately to Strzygowski's exemplification of his method in the book on Armenian architecture referred to above. But what we find there is more puzzling than otherwise. There is a section on Armenian society, another on the Armenian architects, and a third on art appreciation in Armenia. It is certainly hard to see how the first and third of these sections relate to the Inhalt of the table, while the second section is merely artist biography.

If we care to look further into this matter of Inhalt we can consult another application of the method by Potpeschnigg, Planmässige Wescnsforchung in der Dirhthunst, Neue Jahrbücher für Pädagogik, 1917, 209. In this instance the work under discussion is Kleist's Prinz von. Homburg. Again, after a somewhat hesitating location of the Inhalt of the drama in the transformation of the 
titular character, a matter which had already, however, been taken up in connection with the other characters, there follows a biographical section on Kleist. Judging from these examples one must conclude that this species of Inhalt is not something residing in the work and derivable from it but is rather something akin to external historical commentary. If that is the case, Inhalt is not the best name for it. The matter which in his book Strzygowski has grouped under Inhalt seems to be in part the effect of the architecture upon people other than the artist; that is, the matter falls completely out of this table of the relation between the artist and the world.

Glück has done well to omit Inhalt. For there is a danger in dividing the work of art into meaning and appearance. The artist is an artist precisely because he can put all his meaning into the appearance without any residue of Inhalt. Plato saw this and, because he did not value appearance, condemned art. There is, I believe, a similar confusion in the attempt to cut Gegenstand and Gestalt asunder; if the artist has a Gegenstand independent of his Gestalt it can hardly be anything more pertinent than an engraved title, superimposed upon a work that is indecisive enough to need it.

Instead of this dualistic dissection of a single relationship, it would have been better to consider other important relationships. Most of what Strzygowski has to say under the heading Inhalt in his book on Armenian architecture, namely, the sections on Armenian society and on art appreciation, deals with the relation of the public to the works of art in question. Glück's omission of any corresponding discussion is not because the sculptor of the dragon reliefs was lacking in the matter of relationship to the world (Glück is able to tell us a great deal about such a relationship'), but because we lack information as to the former relation of the public toward these reliefs.

There is yet another relationship to which Glück's book also directs our attention. The first section of his investigation is devoted to the employment of the reliefs. Moreover, this is not only put first but it is in many ways the most important section. It finds no place in Strzygowski's table because he has neglected the relation of the commissioner to the work of art. 
These various outstanding matters will no doubt be detrimental to the simple orderliness of a future, more adequate, tabulation. 'They will possibly make it asymmetrical, just as the old form of the table given at the beginning of this review has been made asymmetrical by the necessity of introducing Handuerk into the later form. But art, like life, is hard to reduce to mere symmetry, Hambidge to the contrary notwithstanding. We have long been thankful to Strzygowski for his efforts to introduce order into chaos and now we may be thankful for the additional clarification of method that Glück's book offers. The little book gives in limited space an amazing amount of food for thought.

\section{JoHN SHaPley.}

Heinrich Glück, Der Breit- und Langhausbau in Syrien, Heidelberg, Winter, 1916. 95 pp.; 49 figs.; 4 pls.; 4 to.

In America the great work of Professor Butler in paving the way by a series of expeditions for the study of the architectural riches of Early Christian Syria has never been adequately appreciated. An eye-opener for us is Glück's contribution, which deals particularly with the geographical problems connected with Syrian architecture. Resting almost wholly on the descriptions and illustrations of Butler (though the reports of others have been utilized as far as they are available for the purpose, and (Glück himself has visited Syria) he has been able to shed considerable light on the problems of Syrian architecture by taking into account the geographical, social, and material considerations involved.

Writing first of the Haurân, Glück points out the close geological and geographical connection of the region with Arabia and its marked isolation from the Mediterranean coast. He follows in the architecture of this region the various stages of the conflict between the longitudinal Hellenistic building and what he calls the lateral Arabic one. The inevitable influence that the lack of wood and the presence of hard rolcanic stone exerted upon the structure and the decoration of the buildings of the Taurân is traced in detail. The massive transverse arches and the flat stone roofs are well known peculiarities. But there are innumerable other matters that vary from building to building according to the interplay of tradition, ne- 